\title{
Characterization of Beta-Tricalcium Phosphate ( $\beta$ - TCP) Produced at Different Process Conditions
}

\author{
Kamrun Nahar U, Shovon B*, Rajib Chandra D, Shujit Chandra P, Shukanta B, Muhammed YM and Sydul Islam MD
}

Department of Applied Chemistry and Chemical Engineering, Noakhali Science and Technology University, Noakhali, Bangladesh

\begin{abstract}
$\beta$ - TCP was synthesized by changing the process parameters and all samples were characterized in terms of density, porosity, XRD and FTIR analysis. Density rose and porosity decreased with rising of pH value and density found maximum $(2.31 \mathrm{~g} / \mathrm{cc})$ at $\mathrm{pH} 10$. Sharp peaks in the XRD diffractograms ensured the crystallinity of samples which increased after calcination and sintering process. Average crystal size was found $28.21 \mathrm{~nm}$. IR spectrum at $943.19 \mathrm{~cm}^{-1}$ and $972.12 \mathrm{~cm}^{-1}$ appeared in FTIR analysis proved the presence of pure $\beta$ - TCP exists in resulting samples. Performance to stress increased with $\mathrm{pH}$ and maximum compressive strength was found at $\mathrm{pH} 10$. Calcination was found maximum $3.485 \mathrm{Nmm}^{-2}$ at $900^{\circ} \mathrm{C}$ minimum $1.352 \mathrm{Nmm}^{-2}$ at $800^{\circ} \mathrm{C}$.
\end{abstract}

Keywords: Synthetic bone substitutes; Calcium phosphate ceramics; Hydroxyapatite; Beta-tricalcium phosphate; Process parameter; Wet chemical method

\section{Introduction}

Synthetic bone substitutes have been getting researcher's attention for the last few decades due to the disadvantages of the conventional autogenous and allogenous bone grafting. Calcium phosphate ceramics are most widely used as synthetic bone substitutes [1]. Among various calcium phosphate ceramics hydroxyapatite (HAP, $\left.\mathrm{Ca}_{10}\left(\mathrm{PO}_{4}\right)_{6}(\mathrm{OH})_{2}\right)$ and Beta-tricalcium phosphate $\left(\beta-\mathrm{TCP}, \mathrm{Ca}_{3}\left(\mathrm{PO}_{4}\right)_{2}\right)$ are getting more concentration due to their biocompatibility and bioactivity [2-4]. The most significant feature of these materials is that they can construct direct chemical bond with bone tissue [5] and this interaction is related with and governed by the physical and chemical properties of the materials [6]. Both HAP and $\beta$ - TCP are extensively used as bone substitute. HAP gets more importance for its use as bioactive and non biodegradable bone replacement material along with excellent mecahnical properties. But poor fracture toughness and wear resistance is being considered as the main shortcomings of HAP [7]. Whereas, $\beta$-TCP is bioresorbable and bioresorption occurs through osteoclastic activity $[8,9]$. Calcium phosphate powders can be synthesized through solid state process and wet chemical process that is neutralization process. Powders with different morphology can be obtained by neutralization process by varying process parameter. Studies show that particles with different physical properties such as surface area, particle size, density, porosity etc. affect the properties as well as performance of the final product [10]. As a result, the resulting powder can be used in different purpose depending on morphological conditions [11].

Though, $\beta$-TCP ceramic is very promising bone replacement material. But its poor mechanical strength and very fast resorption rate decreases its uses. The main objective of this study is to investigate the change in properties of porous beta tri-calcium phosphate produced in wet chemical method upon changing process parameters such as $\mathrm{pH}$, concentration and calcinations temperature. In this study $\beta$-TCP powder was produced at different process conditions and the resulting powders were tested in terms of physical properties and mechanical performance.

\section{Experimental}

\section{Powder synthesis}

This $\beta$-TCP nano powders were synthesized by wet chemical process [12], where $500 \mathrm{ml}$ of $0.4 \mathrm{M}\left(\mathrm{NH}_{4}\right)_{2} \mathrm{HPO}_{4}$ was added (drop wise) over $500 \mathrm{ml}$ of $0.6 \mathrm{M} \mathrm{Ca}\left(\mathrm{NO}_{3}\right)_{2} \cdot 4 \mathrm{H}_{2} \mathrm{O}$ for 3 hours which resulted in the formation of white precipitation. The $\mathrm{pH}$ of the suspension was maintained throughout the mixing process. The resulting white suspension was then stirred for $24 \mathrm{~h}$ by magnetic stirrer at room temperature which followed by filtration and the precipitate was washed with distilled water and then with $90 \%$ ethanol to improve the dispersion characteristic. It was then formed into a cake upon drying at $80^{\circ} \mathrm{C}$ for 24 hours and then crushed into powder and then calcined at $900^{\circ} \mathrm{C}$ for 3 hours. This sample was then preserved for characterization and termed as Sample S1 throughout the study.

Beside this, 9 different TCP samples were prepared by varring process parameters. These samples were: Sample $\mathrm{S}_{2}$ ( $\mathrm{pH}$ changed to 6 instead of 8), Sample S3 ( $\mathrm{pH}$ changed to 2, this sample cannot be prepared as it get dissolved in this $\mathrm{pH}$ ), Sample $\mathrm{S} 4$ ( $\mathrm{pH}$ changed to 10), Sample S5 (Concentration of $\left(\mathrm{NH}_{4}\right)_{2} \mathrm{HPO}_{4}$ changed to $0.6 \mathrm{M}$ instead of $0.4 \mathrm{M}$ ), Sample $\mathrm{S} 6$ (concentration of $\mathrm{Ca}\left(\mathrm{NO}_{3}\right)_{2} .4 \mathrm{H}_{2} \mathrm{O}$ changed to $0.8 \mathrm{M}$ instead of $0.6 \mathrm{M})$, Sample S7 $\left(\left(\mathrm{NH}_{4}\right)_{2} \mathrm{HPO}_{4}\right.$ changed to $\left.0.2 \mathrm{M}\right)$, Sample $\mathrm{S} 8\left(\mathrm{Ca}\left(\mathrm{NO}_{3}\right)_{2} \cdot 4 \mathrm{H}_{2} \mathrm{O}\right.$ changed to $\left.0.4 \mathrm{M}\right)$, Sample $\mathrm{S} 9$ (Calcined at $800^{\circ} \mathrm{C}$ ) and Sample $\mathrm{S} 10$ (Calcined at $\left.1000^{\circ} \mathrm{C}\right)$.

\section{Characterization}

Universal Testing Machine (FS-300, Testometric, England) was used to prepare TCP pellets from previously synthesized TCP powders which was then sintered in an electrical tube furnace (GSL-1600*40) in argon atmosphere at $1100^{\circ} \mathrm{C}$ temperature. Bulk density of the sintered TCP pelletis calculated from mass to volume ratio and that was used to calculate the porosity of sintered TCP [13], Total porosity $=1-\mathrm{M} /(\mathrm{V} \times$ $D)$. Where, $M=$ mass of the sintered sample, $V=$ volume of the sintered sample, $\mathrm{D}=$ density of the sintered sample. The phase analysis of the

*Corresponding author: Shovon B, Department of Applied Chemistry and Chemical Engineering, Noakhali Science and Technology University, Noakhali-3814 Bangladesh, Tel: +8801726584853; E-mail: shovon_nstu@yahoo.com

Received: February 28, 2017; Accepted: March 17, 2017; Published: March 25 , 2017

Citation: Nahar UK, Shovon B, Chandra RD, Chandra SP, Shukanta B, et al (2017) Characterization of Beta-Tricalcium Phosphate ( $\beta$ - TCP) Produced at Different Process Conditions. J Bioengineer \& Biomedical Sci 7: 221. doi: 10.4172/2155-9538.1000221

Copyright: $\odot 2017$ Nahar UK, et al. This is an open-access article distributed under the terms of the Creative Commons Attribution License, which permits unrestricted use, distribution, and reproduction in any medium, provided the original author and source are credited. 
Citation: Nahar UK, Shovon B, Chandra RD, Chandra SP, Shukanta B, et al. (2017) Characterization of Beta-Tricalcium Phosphate ( $\beta$ - TCP) Produced at Different Process Conditions. J Bioengineer \& Biomedical Sci 7: 221. doi: 10.4172/2155-9538.1000221

Page 2 of 4

TCP was conducted in room temperature with $\mathrm{Cu}-\mathrm{Ka}(\lambda=0.15406 \mathrm{~nm})$ radiation in a continuous mode from ${ }_{2} \theta$ range ${ }_{2} 0-70^{\circ}$ with a scanning rate of $2^{\circ}$ per min by using Bruker: D8 ADVANCE XRD with SAX.

Subsequently average crystallite size of the TCP at $1100^{\circ} \mathrm{C}$ is calculated from X-ray line broadening using the Scherrer's equation [14] as:

$$
\mathrm{D}=\frac{0.89 \lambda}{\beta \cos \theta}
$$

Where, $\mathrm{D}$ is the crystallite size, $\lambda$ is the $\mathrm{X}$-ray wavelength $(1.5406$ $\AA$ ) of $\mathrm{Cu}-\mathrm{Ka}$ radiation, $\theta$ is the Bragg's angle and $\beta$ is the full width at half-maximum (FWHM).

Chemical groups on the surface of calcined powders were analyzed by FTIR (PerkinElmer: Frontier FT-IR/NIR) in the wavenumber range 400 to $4000 \mathrm{~cm}^{-1}$. In this regard the calcined powder was grinded with $\mathrm{KBr}$.

Mechanical properties were observed using TMA (S11 TMA/ SS6300i).

Compressive strength wasmeasured by using Hertz equation [15]:

$$
\sigma_{\text {comp. }}=\left(\frac{2 P}{\pi D T}\right)
$$

with the help of universal testing machine (Hounsfield H10K-S, U.K). Where, $\sigma_{\text {comp }}$ is compressive strength, $\mathrm{P}$ is breaking load, D is diameter of the sintered compact, $\mathrm{T}$ is thickness of the sintered compact.

\section{Results and Discussion}

Bulk density and apparent porosity of different TCP samples were given in the Table 1 . ResultS showed that the density was found maximum $(2.31 \mathrm{~g} / \mathrm{cc})$ at $\mathrm{pH} 10$ and it increased with the risen of $\mathrm{pH}$ value. Porosity was maximum $(40.92 \%)$ when standard condition was followed. Both the density and the porosity found minimum $(1.64 \mathrm{~g} / \mathrm{cc}$ and $23.50 \%$ respectively) when $\left(\mathrm{NH}_{4}\right)_{2} \mathrm{HPO}_{4}$ conc. was $0.2 \mathrm{M}$. Figures 1-3 showed the XRD pattern of TCP samples sintered at different condition.

Sharp peaks in the diffractogram ensured that the products were well crystallized. The resulting graph was also well matched with the standard pattern of $\beta$-TCP or whitlockite with presence of a small amount of HAP in dried sample and very small amount of $\alpha$-TCP. But, comparison with the whitelockite and sharpness of the graph indicates that crystallinity of all TCP samples increased after calcination and sintering procedure.

Average crystallite size of sintered $\beta$-TCP powder (computed by using Scherrer's formula) was found $28.21 \mathrm{~nm}$. The IR characteristic peaks of phosphate groups appeared between $900-1160 \mathrm{~cm}^{-1}$. The peak at $943.19 \mathrm{~cm}^{-1}$ and $972.12 \mathrm{~cm}^{-1}$ proved the presence of pure $\beta$-TCP. All the bands between $900-1200 \mathrm{~cm}^{-1}$ range represented the stretching mode of $\mathrm{PO}_{4}^{3-}$ group. Peaks at $725.2 \mathrm{~cm}^{-1}$ and $1209.37 \mathrm{~cm}^{-1}$ attributed to the presence of $\mathrm{P}_{2} \mathrm{O}_{7}^{4-}$ group, which was characteristic to calcium pyrophosphate phase. For all the samples similar types of graph was found that proved the presence of pure $\beta$-TCP in the working Samples (Figure 4).

Compression test determined the limit of performance of a material to stress. The maximum compressive strength was found for Sample 4 ( $\mathrm{pH} \mathrm{10)}$ and minimum compressive strength was found for

\begin{tabular}{|c|c|c|}
\hline Sintered sample & $\begin{array}{c}\text { Density(g/ } \\
\text { cc) }\end{array}$ & Porosity (\%) \\
\hline Sample S-1, where standard condition was \\
followed & 1.88 & 40.92 \\
\hline Sample S-2, where $\mathrm{pH}$ was 6 instead of 8 & 1.67 & 40 \\
\hline Sample S-4, where $\mathrm{pH}$ was 10 instead of 8 & 2.31 & 25.23 \\
\hline Sample S-5, $\left(\mathrm{NH}_{4}\right)_{2} \mathrm{HPO}_{4}$ conc. was 0.6M & 2.08 & 26.57 \\
\hline Sample S-6, $\mathrm{Ca}\left(\mathrm{NO}_{3}\right)_{2} \cdot 4 \mathrm{H}_{2} \mathrm{O}$ conc. was 0.8M & 1.81 & 31.59 \\
\hline Sample S-7, $(\mathrm{NH} 4)_{2} \mathrm{HPO}_{4}$ conc. was 0.2M & 1.64 & 23.5 \\
\hline Sample S-8, $\mathrm{Ca}\left(\mathrm{NO}_{3}\right)_{2} \cdot 4 \mathrm{H}_{2} \mathrm{O}$ conc. was 0.4M & 1.76 & 38.89 \\
\hline Sample S-9, where calcination temp. was 800॰C & 1.75 & 33.34 \\
\hline Sample S-10, where calcination temp. was & 2.11 & 40.9 \\
\hline $1000 \circ \mathrm{C}$ & & \\
\hline
\end{tabular}

Table 1: Density and porosity of $\beta$-TCP samples.

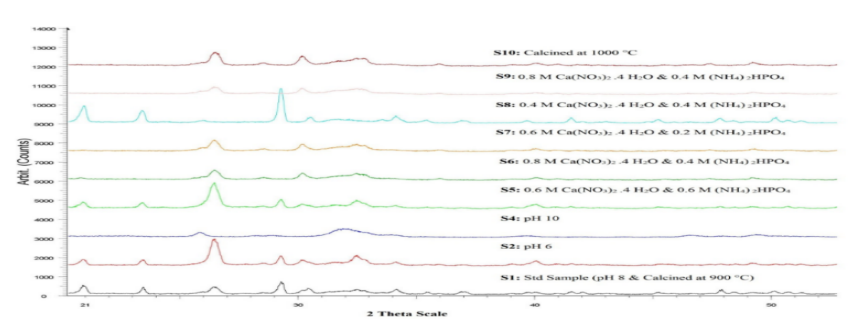

Figure 1: XRD pattern of dried TCP.

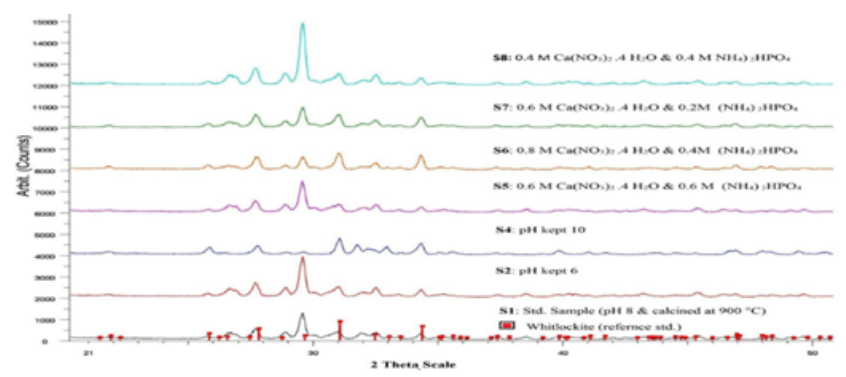

Figure 2: XRD pattern of calcined TCP.

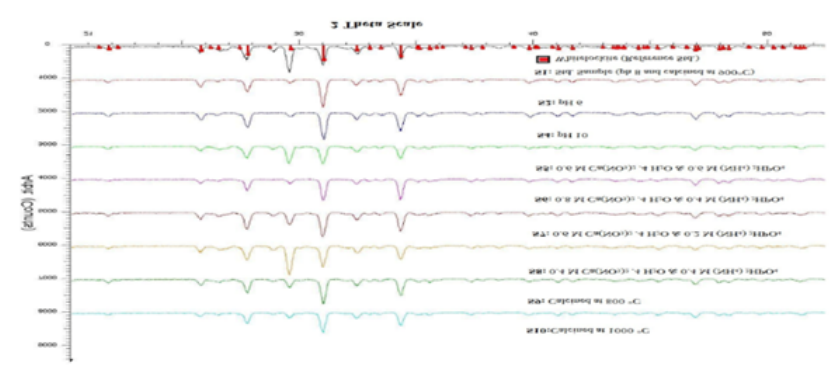

Figure 3: XRD pattern of sintered TCP.

Sample 9 (calcined at $800^{\circ} \mathrm{C}$ ). It is due to the fact that the porosity of TCP decreased with increased of $\mathrm{pH}$ as a result compressive strength increased. On the other hand, low calcination temperature resulted in poor density that was higher porosity which caused poor compressive strength (Table 2).

Thermal expansion coefficient value showed very small variation with changing the parameters. These values of thermal expansion coefficient were listed in Table 3 . The minimum value was $1.389 \times 10^{-5}$ and 
Citation: Nahar UK, Shovon B, Chandra RD, Chandra SP, Shukanta B, et al. (2017) Characterization of Beta-Tricalcium Phosphate ( $\beta$ - TCP) Produced at Different Process Conditions. J Bioengineer \& Biomedical Sci 7: 221. doi: 10.4172/2155-9538.1000221
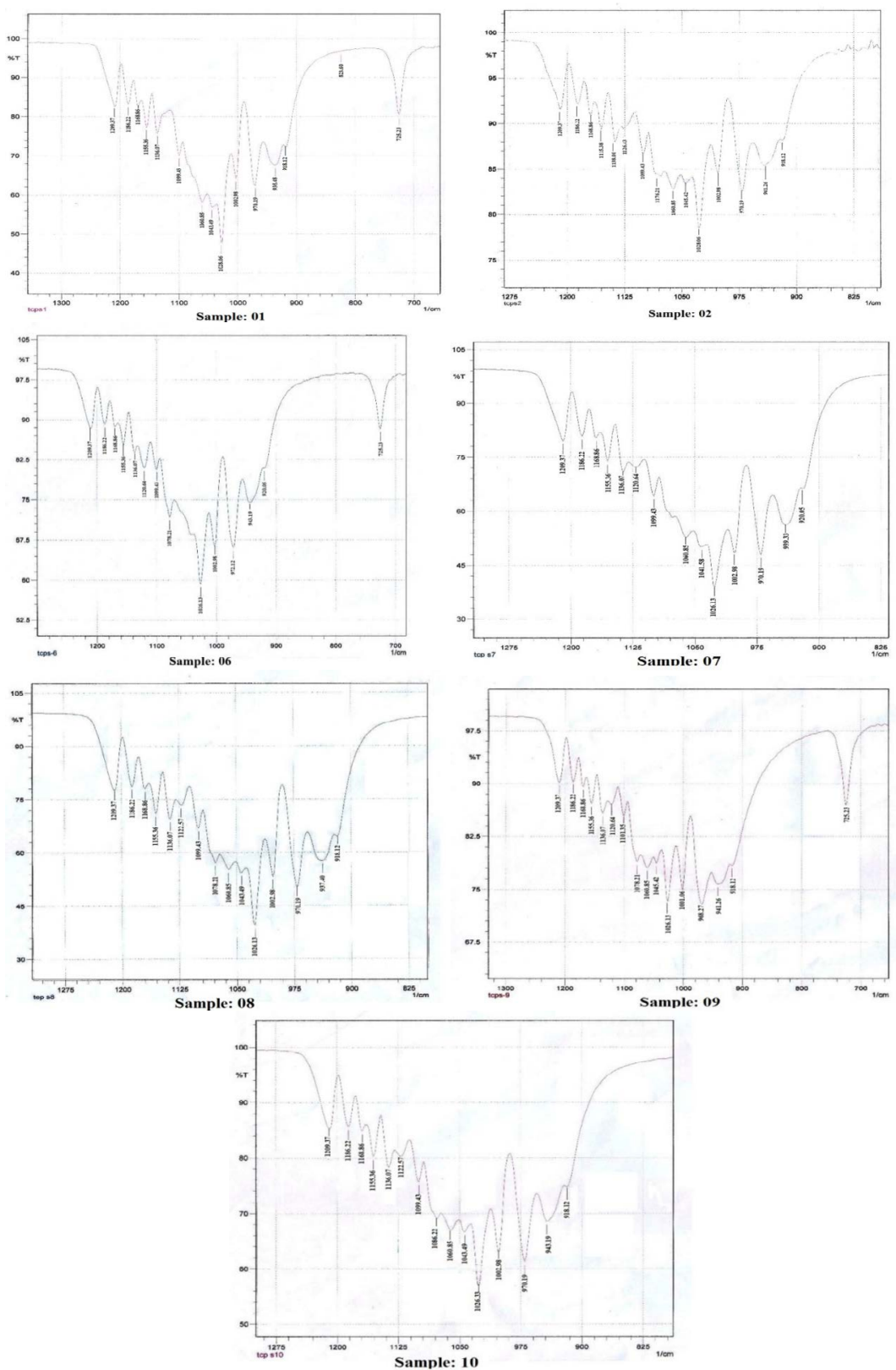

Figure 4: FTIR spectra of different samples of $\beta$-TCP powder (Samples 1, 2, 6-10)

\begin{tabular}{|c|c|}
\hline Sintered sample & B- TCP $\left(\mathbf{N m m}^{-2}\right)$ \\
\hline sample S-1, where standard condition was followed & 3.485 \\
\hline Sample S-2, where $\mathrm{pH}$ was 6 instead of 8 & 1.812 \\
\hline Sample S-4, where $\mathrm{pH}$ was 10 instead of 8 & 13.402 \\
\hline Sample S-5, $\left(\mathrm{NH}_{4}\right)_{2} \mathrm{HPO}_{4}$ conc. was $0.6 \mathrm{M}$ & 4.774 \\
\hline Sample S-6, $\mathrm{Ca}\left(\mathrm{NO}_{3}\right)_{2} \cdot 4 \mathrm{H}_{2} \mathrm{O}$ conc. was $0.8 \mathrm{M}$ & 8.858 \\
\hline Sample S-7, $\left(\mathrm{NH}_{4}\right)_{2} \mathrm{HPO}_{4}$ conc. was $0.2 \mathrm{M}$ & 5.222 \\
\hline Sample S-8, $\mathrm{Ca}\left(\mathrm{NO}_{3}\right)_{2} \cdot 4 \mathrm{H}_{2} \mathrm{O}$ conc. was $0.4 \mathrm{M}$ & 3.804 \\
\hline Sample S-9, where calcination temp. was $800^{\circ} \mathrm{C}$ & 1.352 \\
\hline Sample S-10, where calcination temp. was $1000{ }^{\circ} \mathrm{C}$ & 1.614 \\
\hline
\end{tabular}

Table 2: Compressive strength of $\beta$-TCP powder.

maximum value was $1.505 \times 10^{-5}$.Coefficient of Thermal Expansion of $\beta$-TCP powder obtained from TMA (Table 3).

\section{Conclusion}

Different samples of $\beta$-TCP nano powders were prepared by varying process parameter. All these parameters effects on the properties of the resulting $\beta$-TCP nano powders. Density and porosity changes with the $\mathrm{pH}$ changes and crystalinity changes with calcination. But, compressive strength found maximum at $900^{\circ} \mathrm{C}$.

Furthermore, widespread use required in situ test and site testing. For long term use both laboratory and full scale loading tests are required and needed to develop a database for assesment.

\section{Acknowledgement}

I acknowledge with gratitude to Department of Pilot Plant and Process Development Centre, Bangladesh Council of Scientific and Industrial Research, Dhaka-1205 for their outstanding support in instrumental/technical section such as 
Citation: Nahar UK, Shovon B, Chandra RD, Chandra SP, Shukanta B, et al. (2017) Characterization of Beta-Tricalcium Phosphate ( $\beta$ - TCP) Produced at Different Process Conditions. J Bioengineer \& Biomedical Sci 7: 221. doi: 10.4172/2155-9538.1000221

\begin{tabular}{|l|l|}
\hline \multicolumn{1}{|c|}{ Sintered sample } & Thermal Expansion Coefficient $\left(\mathrm{K}^{-1}\right)$ \\
\hline $\begin{array}{l}\text { Sample S-1, where standard condition was } \\
\text { followed }\end{array}$ & $1.481 \times 10^{-5}$ \\
\hline Sample S-2, where $\mathrm{pH}$ was 6 instead of 8 & $1.505 \times 10^{-5}$ \\
\hline Sample S-4, where $\mathrm{pH}$ was 10 instead of 8 & $1.389 \times 10^{-5}$ \\
\hline Sample S-5, $\left(\mathrm{NH}_{4}\right)_{2} \mathrm{HPO}_{4}$ conc. was $0.6 \mathrm{M}$ & $1.538 \times 10^{-5}$ \\
\hline Sample S-6, $\mathrm{Ca}\left(\mathrm{NO}_{3}\right)_{2} \cdot 4 \mathrm{H}_{2} \mathrm{O}$ conc. was $0.8 \mathrm{M}$ & $1.471 \times 10^{-5}$ \\
\hline Sample S-7, $(\mathrm{NH} 4)_{2} \mathrm{HPO}^{-5}$ conc. was $0.2 \mathrm{M}$ & $1.394 \times 10^{-5}$ \\
\hline Sample S-8, $\mathrm{Ca}\left(\mathrm{NO}_{3}\right)_{2} \cdot 4 \mathrm{H}_{2} \mathrm{O}$ conc. was $0.4 \mathrm{M}$ & $1.498 \times 10^{-5}$ \\
\hline $\begin{array}{l}\text { Sample S-9, where calcination temp. was } \\
800 \circ \mathrm{C}\end{array}$ & $1.505 \times 10^{-5}$ \\
\hline $\begin{array}{l}\text { Sample S-10, where calcination temp. was } \\
1000 \circ \mathrm{C}\end{array}$ & \\
\hline
\end{tabular}

Table 3: Coefficient of thermal expansion of $\beta$-TCP powder.

different sample analysis by using their laboratory.

\section{References}

1. Jarcho M (1981) Calcium phosphate ceramics as hard tissue prosthetics. Clin Orthop Rel Res 157: 259-278.

2. Gibson LJ (2003) Cellular solids. MRS Bull 28: 270-274.

3. Wang S, Jain H (2010) High surface area nanomacroporous bioactive glass scaffold for hard tissue engineering. J Am Ceram Soc 93: 3002-3005.

4. Fabbri M, Celotti GC, Avaglioli A (1994) Granulates based on calcium phosphate with controlled morphology and porosity for medical applications: Physicochemical parameters and production technique. Biomaterials 6: 474-477.
5. Tancred DC, Mccormack BAO, Carr AJ (1998) Synthetic bone implant macroscopically identical to cancellous bone. Biomaterials 19: 2303-2311.

6. Daculsi G, Passuti N (1990) Effect of the macroporosity for osseous substitution of calcium phosphate ceramics. Biomaterials 11: 86-87.

7. Cen Y, Zhang TH, Gan CH, Yu G (2007) Wear studies of hudroxiapatite composite coating reinforced by arbon nanotubes. Carbon 45: 998-1004.

8. Klein CPAT, Driessen AA, Groot K, Hoof A (1983) Biodegradation behavior of various calcium phosphate materials in bone tissue. J Biomed Mater Res 17 769-784.

9. Eggli PS, Muller W, Schenk RK (1988) Porous hydroxyapatite and tri-calcium phosphate cylinders with two different pore size ranges implanted in the cancellous bone of rabbit. Clinical Orthop 232: 127-138.

10. Patel N, Gibson IR, Ke S, Best SM, Bestbonfield W (2001) Calcining influence on the powder properties of hydroxyapatite. J Mater Sci Mater Med 12: 181188.

11. Prakash KH, Kumar R, Ooi CP, Cheang P, Khor KA (2006) Apparent solubility of hydroxyapatite in aqueous medium and its influence on the morphology of nano-crystallites with precipitation temperature. Langmuir 22: 11002-11008.

12. Mirhadi B, Mehdikhani B, Askari N (2011) Synthesis of nano-sized $\beta$-tricalcium phosphate via wet precipitation. Processing and Application of Ceramics 5 : 193-198.

13. Miao X, Tan DM, Li J, Yin X, Ross C (2008) Mechanical and biological properties of hydroxyapatite/tricalcium phosphate scaffolds coated with poly (lactic-coglycolic acid). Acta Biomater 4: 638-645.

14. Scherrer $P$ (1939) The scherrer formula for $X$-ray particle size determination. Phys Rev 56: 978-982.

15. Li D, Wong LNY (2013) The Brazilian disc test for rock mechanics applications: Review and new insights. Rock Mech Rock Eng 46: 269-287. 